\title{
Disrupt, Support and Document: The Role of Social Media in International Parental Child Abduction Cases involving Japan
}
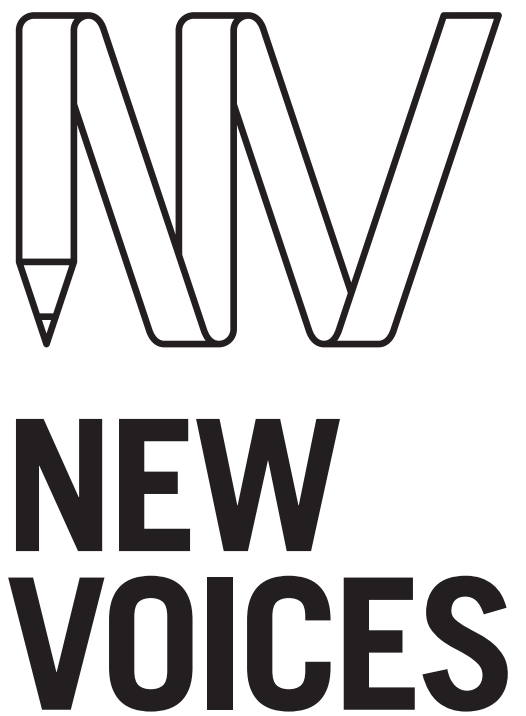

IN JAPANESE STUDIES

\section{GERALDINE CARNEY}

Monash University

\section{ABSTRACT}

In this article, I examine the use of social media by parents involved in cases of international parental abduction to and from Japan, with a focus on cases of abduction to Japan. I argue that the use of social media in these cases is a symptom of and a counter to a legal system which has been outpaced by changes in society, particularly the creation and dissolution of international families. This article discusses a number of case studies of social media usage and locates these in the context of the contemporary Japanese legal system. While not ignoring the nefarious potential of social media usage, I come to a positive assessment of its use in cases of international parental child abduction involving Japan. I also question how its utility will change over time, depending on the legal system's ability to adapt to societal changes and expectations.

\section{KEYWORDS}

custody disputes; Facebook; family law; human rights; intermarried families; international law; international relations; internationalisation; law; media; parental child abduction; social media; technology

\section{JAPANFOUNDATION \& \\ BRINGING JAPAN TO YOU \\ To link to this article: \\ http://dx.doi.org/10.21159/nvjs.08.01}

\section{ISSN 2205-3166}

New Voices in Japanese Studies is an interdisciplinary, peer-reviewed journal showcasing the work of emerging scholars from Australia and New Zealand with research interests in Japan.

All articles can be downloaded free at newvoices.org.au

(c) The Japan Foundation, Sydney and Geraldine Carney, 2016

\section{cc) $\$$}




\section{INTRODUCTION}

Every character and function that interactive digital media facilitates can be seen as double-sided, where the dark side inevitably connects to the light.

(Åkerström 2015, 120)

The advent of social media has affected almost every aspect of contemporary life. The political and legal spheres concerned with creating policy for control and implementing these policies through law are still coming to grips with how their work is changing in the wake of new forms and unprecedented levels of social communication. At times, the heightened level of social connection produced by social media aids policy making and justice; at other times, it complicates and disrupts.

The area of human rights offers many examples of the complicated intersection between legal and political processes and the use of social media. For example, social media was lauded for its role in the democratic uprisings known as the 'Arab Spring' in the Middle East and North Africa region in 2011, where it provided freedom of expression and a means of organising in otherwise tightly controlled societies (see Khondker 2011; Joseph 2012). Even so, others have argued that social media can be used as an insidious form of social control and surveillance by state agencies (see Morozov 2011; Fuchs et al. 2012).

One human rights issue which has become more prominent in an increasingly connected and internationalised ${ }^{1}$ world is that of cross-border child custody issues and, in particular, international parental child abduction. ${ }^{2}$ This paper examines the issue of cross-border parental child abduction ('international parental child abduction') involving Japanese nationals. In particular, it considers the role that social media plays in cases of international parental child abduction, which are by their very nature emotionally charged and often politically and legally complex.

I argue that custody laws in Japan are being outpaced by changes in society. That is, the legal system is struggling to address issues arising from the union and dissolution of international families which are now common in Japanese society, as well as the increasingly vocal refusal of parents, Japanese and non-Japanese alike, to be excluded from their children's lives after divorce. ${ }^{3}$

1 This paper adopts the explanation of internationalisation proffered by Breaden and Stevens $(2014,4)$ as a "conscious and often intentional" process in which the action is the focus, as opposed to globalisation, in which the product is the focus. This theoretical basis seems most appropriate in the context of cross-border relationships as acts of internationalisation, albeit in a globalised world.

2 International parental child abduction is also a human rights issue, from the viewpoint of many Western family law systems that it is "largely unquestionable" that most children benefit from an "ongoing, warm and available involvement of both parents, in a climate of well-managed interparental conflict" (McIntosh 2009, 389; see also Jaffe 2014). While it is out of the scope of this paper, of relevance is the discussion as to the existence of human rights (see Mégret 2011, 200-204), as well as whether parents can be regarded as having rights with respect to their children (as opposed to duties and obligations) (see Austin 2013).

3 A Tokyo Family Court committee meeting in December 2011 recognised that visitation cases handled by the Japanese family courts between 1999 and 2010 had increased 3.6 times, and the proportion of applications made through the Japanese family courts by fathers had also increased from $53 \%$ to $66 \%$ in that time (Supreme Court of Japan 2011, 3-4). The committee noted various reasons for the increase in applications for visitation by fathers after divorce: an increase in the overall number of divorces, the changing role of the father and the increase in the number of households where mothers and fathers split the management of the household and child-rearing, and a change in societal views about the importance of visitation by the non-custodial parent (Supreme Court of Japan 2011, 4-6). 
As the legal system does not keep pace with social developments, social media is utilised by concerned parties to help fill the gap: to document their cases, call for support and sway public opinion, and potentially disrupt the status quo on custody issues.

The relationship between social media and the advancement of human rights is complex, multi-layered and still emerging. It is a relationship which is double-sided, as suggested by Åkerström (2015) above. While not ignoring the tension in this relationship and the "dark side" $(2015,120)$ of mass digital communication, I argue for an ultimately optimistic assessment of the role of social media in international parental child abduction cases involving Japan, as it can assist parties involved to at least partially fill the gaps in the available legal remedies. I also recognise the changing legal landscape in Japan and suggest that the role of social media in international parental abduction cases may alter over time.

\section{INTERNATIONAL PARENTAL CHILD ABDUCTION AS A JAPANESE STUDIES ISSUE: THE LEGAL “BLACK HOLE” OF JAPAN}

Parental child abduction occurs when one parent removes their child or retains them in breach of the other parent's rights of custody according to laws of the jurisdiction governing the parent-child relationship prior to the removal or retention. There is a raft of international and domestic laws and regulations designed to decrease the incidence of parental child abduction and to offer legal relief to 'left-behind parents' whose children have been parentally abducted. Parental child abduction is not a new phenomenon. However, it only began to be regarded as a legal and social problem in the 1970s, in the wake of growing public concern regarding child welfare and issues which were traditionally considered private affairs, such as family violence (Greif and Hegar 1993). Much of the early research which posited parental child abduction as an important social issue grew from the American legal and psychosocial context (e.g. Bodenheimer 1977; Terr 1983; Agopian 1984; Sagatun and Barrett 1990).

International parental child abduction-that is, parental child abduction occurring over national borders-is an increasingly common corollary of the rise of internationalisation, forces of globalisation and accompanying human mobility between nationalities, ethnicities and cultures. ${ }^{4}$ Certainly, these factors have affected Japanese citizens' work, education, travel and leisure choices, and have inspired the flow of people across its borders in an unprecedented way. Transnational relationships are increasing. The number of marriages in Japan where one spouse is of a nationality other than Japanese increased five-fold between 1965 and 2014, from 4,156 to 21,130 (Ministry of Health, Labor and Welfare 2014, Table 9.18).

This trend is reflected at a judicial and administrative level in Japan: the total number of new international family law cases handled by Japanese family 
courts has grown from 5,726 in 2000 to 8,441 in 2014, representing a $47.4 \%$ increase (Supreme Court of Japan 2000, 26; Supreme Court of Japan 2014, 30). ${ }^{5}$ Of those cases, the number identified as involving the designation of physical custody of a child and related issues, or the designation or alteration of legal custody of a child, increased from 656 to 1295, representing a 97\% increase (Supreme Court of Japan 2000, 26; Supreme Court of Japan 2014, 30). The total number of cases of the same designation (international and domestic) handled by Japanese family courts in the same period rose 79\% (Supreme Court of Japan 2000, 6-7; Supreme Court of Japan 2014, 8-9). This difference does not necessarily indicate that the actual number of international custody disputes is increasing at a faster rate in Japan, but it does establish that these cases are rapidly becoming more visible at an institutional level.

It should be noted that these statistics are only indicative of a potentially much larger issue, as the vast majority of divorces in Japan are completed by consent and without the involvement of the family courts or other third party: the requisite paperwork is simply completed by the parties and filed with the local government office (Jones 2007, 205; Tsuneoka 2013, 40). These divorces by consent are known as kyōgi rikon (協議離婚) ${ }^{6}$, and constituted $87.4 \%$ of divorces in Japan in 2014 (Ministry of Health, Labor and Welfare 2014, Table 10.4). It follows that the overall number of children of failed international relationships would be much greater than the number of judgements and mediations for these types of cases. Also, these figures do not necessarily reflect divorces involving Japanese citizens that are concluded overseas.

The number of children parentally abducted to and from Japan is unknown. Up until recently, there has been no formal mechanism for recording abduction cases in Japan, and governments of other countries have relied on reports made voluntarily to them by aggrieved parents. As of 2013, the United States counted 100 active cases of abduction to Japan involving more than 140 children (U.S. Department of State 2013). There were also reported to be at least 37 British nationals involved in parental abduction cases to Japan as at 2013 (Ryall 2013), and 33 cases of reported abductions of French children to Japan (Vaulerin 2013). In Australia, there are reports of up to 15 children having been abducted to Japan (Australians with Abducted Children 2013). While the precise number of international parental child abduction cases is unclear, there is evidence that they are becoming more frequent. The U.S. Embassy in Japan (2010) reported that the number of international parental child abductions to Japan tracked by the United States, the United Kingdom, Australia, Canada and France indicated that parental child abductions to Japan from these five countries had almost doubled in the previous two years, and more than quadrupled in the previous four years.

These figures may not reflect the true magnitude of the issue, when it is considered that the overwhelming majority of transnational marriages in Japan involve individuals from countries outside North America, Australia and Europe. In 2014, non-Japanese brides hailed from China and the Philippines

5 In Japan, international family law cases are defined as judgements or mediations (調停) in which at least one of the parties is non-Japanese.

6 This and other Japanese terms used are listed in a glossary at the end of this paper.

Geraldine Carney New Voices in Japanese Studies, Vol. 8, 2016, pp. 1-31 
in $40.1 \%$ and $20.0 \%$ of cases respectively, while non-Japanese husbands were most commonly Korean (North and South), accounting for $27.7 \%$ of transnational marriages with Japanese wives in the same year (Ministry of Health, Labor and Welfare 2015, Table 9.19; Ministry of Health, Labor and Welfare n.d.). The predominance of these particular pairings is reflected in the numbers of international divorce-related cases handled by the family courts in Japan. In 2014, cases involving a Filipina wife and Japanese husband accounted for 381 of 1,949 international divorce-related cases (approximately $19.5 \%$ ), while cases involving a Chinese wife and Japanese husband accounted for 265 cases (approximately 13.5\%), by far the highest-ranking pairings amongst the tallied cases (Supreme Court of Japan 2014, 50). In cases involving non-Japanese husbands, disputes between South Korean husbands and Japanese wives were the most common, accounting for 87 cases of the 1,949 international divorce-related cases (approximately 4.4\%). The incidence of parental abduction cases within these groups is unknown.

Given the lack of rigour in the reporting of international parental abduction cases, it can be difficult to distil any significance from a comparison of abductions to and from Japan with international parental abduction figures globally. However, to provide context, the Hague Conference reported in its most recent statistical analysis in 2011 that the number of return applications (the request to have a child returned) registered in 2008 by 60 of its then 81 contracting states was 1,961, involving 2,705 children (Hague Conference on Private International Law 2011, 5, 6 and 10). These statistics are heavily qualified by the fact that they do not account for abductions within state borders or where return applications were made under other inter-country agreements $(2011,5)$.

Japan's management of international parental child abduction cases involving its citizens has attracted sharp criticism from the international community for many years. Despite there being some public interest in parental child abduction involving Japan at an earlier stage (e.g., Buckland 2006), it is arguable that the issue did not gain full public attention until 2009, when Tennessee resident Christopher Savoie was arrested and spent eighteen days in jail in Fukuoka, Japan, on suspicion of attempted abduction of his two children from his Japanese ex-wife, Noriko Savoie (Lah 2009). Noriko Savoie had removed the children to Japan from the United States in violation of a Tennessee court order granting Christopher Savoie rights of access (Warner 2010, 50). The facts of the Savoie marriage, divorce and custody dispute are, like any, complex and nuanced, but the story gained international coverage and was framed by the English-language media in simplified terms as a battle between American and Japanese law and culture (e.g., Saltzman 2009). Christopher Savoie was not the first left-behind parent to be arrested in these circumstances, but his case was credited with raising public awareness internationally and precipitating increased diplomatic pressure on Japan to address cases of custody disputes in a more balanced way (Saltzman 2009; see also Toland 2011).

Japanese society has often been described by English-language media as a "black hole" (e.g., Jones 2011b; Willacy 2012) or "haven" (e.g., Birmingham 2011; McCurry 2013) for parental abduction. Many commentators, predominantly 
in the mainstream western media, have lamented the dearth of legal avenues available in Japan to left-behind parents to assist in locating children and enforcing their custodial or visitation rights as recognised in another state (Dingle 2011; Bramham 2013). In particular, Japan has been criticised for protecting Japanese abductors and freezing out foreign parents from the lives of their children (Buerk 2011). The criticism levelled at the Japanese legal system's handling of international parental child abduction cases has been directed at two key areas: namely, the way parental abduction cases are handled within the domestic legal system, and Japan's engagement with international law. In 2014, Japan became a contracting party to the Hague Convention of 25 October 1980 on the Civil Aspects of International Child Abduction ('Hague Abduction Convention'), which is the key legal mechanism in international law to address the issue of international parental child abduction. This was an important milestone in the management of parental child abduction by Japan and provided a new focus for the narrative of this international social, legal and political issue.

\section{THE ROLE OF SOCIAL MEDIA IN INTERNATIONAL PARENTAL CHILD ABDUCTION CASES}

Despite its wide use in social, commercial and academic contexts, the term 'social media' tends to defy conventional academic definitions due to its disparate and evolving nature. It may be broadly understood as a set of mobile and web-based platforms which allow users to generate and share online content for the purpose of collaborating and building networks and communities, with the potential for connecting with a larger audience (El Ouirdi et al. 2014, 123).

\section{Methodology}

Case studies of parents involved in parental child abductions are a key source of data in my larger research. The case of the Savoie family provided a natural starting point for my case study selection, as it is very visible in both a discursive and practical sense. The case is widely cited and employed to frame a narrative for the issue, at least in English-language media and academic works that critically address the legal approach of the Japanese government. The awareness raised by the Savoie case has also translated into increased political and diplomatic pressure on Japan to change the way the Japanese government handles cases of parental abduction. In this way, the case signifies a turning point in the international history of the parental child abduction issue. Many elements of the Savoie case were extraordinary. For this reason, the case is a valuable source of information and can perhaps provide further insight into the legal conditions in Japan, beyond its own specific set of facts (see Flyvbjerg 2006, 229-33).

In selecting my other case studies, I have sought to provide a counterpoint to the Savoie case by selecting cases that involve a range of legal systems and traditions, countries and family relationships. I employ a thematic narrative 
analysis (see Riessman 2008, 53-76; see also Polkinghorne 1995 on the "analysis of narrative") to identify common threads and points of discord in the cases. I further employ a narrative constructionist approach to connect the narrative to the historical, political and sociocultural context (Esin et al. 2013, 20315). ${ }^{7}$ This approach is consistent with the sociolegal conceptual framework, which seeks to contextualise legal developments rather than treating them as self-contained subjects of analysis. My guiding thesis is that there are gaps arising between the current state of Japanese divorce and custody laws and the increasing internationalisation of marriage.

Some of my selected cases are easily located in mainstream media. Others have attracted little or no publicity at all. While some left-behind parents may, understandably, seek to protect their privacy, others wish to share their stories. Social media is an enabler to fill the gap between the realities of international parental child abduction and their portrayals in mainstream media, and can offer another layer to an individual's story. Analysis of the use of social media in my selected case studies led to important additional findings as social media performed the dual role of data collection tool and a site of narrative enquiry (see Squire et al. 2014, 47-48).

\section{Limitations of Social Media as a Research Tool}

While social media is an important tool of contemporary activism (for further discussion see Postmes 2007, 174-79), its usage is heavily tempered by disparate individual circumstances (see Hargittai 2007). This study aims to highlight the different ways in which parties to parental abduction employ social media as an adjunct to the available legal options. It is beyond the scope of this study to address correlations between individual circumstances and social media usage, or to quantify or exhaustively categorise social media usage.

Social media can be conceptualised as a conduit through which individuals present and inhabit a particular image of themselves (Manago et al. 2008). This conceptualisation is a natural extension of the seminal work of Erving Goffman on the presentation of the self (1959). Custody disputes have the potential to firmly entrench parents in polarised positions, perhaps even more so in cases involving Japan, given the 'all or nothing' custody scenario often presented to parents under the family law, as elaborated upon below. It is therefore important to view the social media sites produced in this context with caution and accept that they may be, consciously or not, a presentation of one parent's version of events rather than an objective 'truth'.

\section{The Use of Social Media in Parental Child Abduction Cases}

As well as filling in a gap left by mainstream media coverage, social media content created by both individual and groups of left-behind parents, including Facebook pages, tweets, blogs and online forums, assists to fill the vacuum between the realities of international parental child abduction and 
the legal solutions available to left-behind parents. While this gap creates bitter disappointment, helplessness and despair at the outcomes achievable through law, social media provides an extra-legal platform for left-behind parents to connect and share information with other parents in the same position, wherever there is internet access in the world. It also provides a virtual space for them to continue to advocate for change, even though their individual cases may be lost in legal terms. In some cases, content generated by left-behind parents can play a complementary role to the legal process by providing practical information to other left-behind parents regarding their legal options.

One prevalent way that left-behind parents participate in social media is by joining or subscribing to an online group. The Japan Children's Rights Network (also known as CRN Japan) is an early example of this type of group. Established in 2003, its stated mission is to "disseminate information to help change attitudes and laws in Japan in order to assure all children of direct, meaningful and continuing contact with both parents, regardless of citizenship, marital status or gender" (The Japan Children's Rights Network, n.d.[a]). The group provides a multitude of online resources for left-behind parents, including information on Japanese family law and the practicalities of pursuing custody rights in Japan (such as assessments of local lawyers), as well as a web-based service to assist children in contacting left-behind parents and a space for online discussion. The group also plays a role in assisting parents who suspect their children are about to be abducted by providing information about travel restraining orders and other preventative measures. While not holding itself out as a legal advisor, in the provision of this type of practical assistance the group offers quasi-legal support to parents who may not be able to afford legal advice or may have run into dead-ends in their cases. In this way, it represents an important extension of the legal process.

While CRN Japan has a strong advocacy and legal focus, other groups such as Left Behind Parents Japan, formed via a social networking portal (Meetup. com), are more social, encouraging parents to join and co-operate with one another. Left Behind Parents Japan was started by a Japanese citizen, Masako Akeo, herself a left-behind parent after her Japanese husband abducted their child from their home in Canada (Akeo 2010). The group arranges social functions in Tokyo, as well as events to lobby for changes to the law in Japan. At last count in May 2016, the group had 163 members.

There are also groups who publish their sites in Japanese, such as Chību kyōdōshinken hōseika undō no kai (中部共同親権法制化運動の会; Chubu Joint Custody Association for Legislating of Joint Custody and Joint Nurture), and Kyōdōshinken undō nettowāku (共同親権運動ネットワーク) or K-netto (Kネッ ト), which translates as 'Joint Custody Action Network (K-net)' (Chübu 2016; Kyōdōshinken n.d.). Compared to the Japan Children's Rights Network and similar groups with sites in English (and presumably a large member base of non-Japanese parents), these groups focus on advocating for change to domestic custody laws and local law reform activity, rather than detailing individual cases. This could be due to the fact that sole custody and minimal visitation are accepted as the social norm in Japan and reflected in the extant 
legal system, and case studies are therefore not effective tools in advocating for change. Nevertheless, these sites also represent an attempt to intervene in the social and legal status quo with respect to the child custody system in Japan, of which the Hague Abduction Convention is only one part.

In addition to social media groups, the online activities of individual leftbehind parents and their supporters can also provide an outlet for advocacy and support. Christopher Savoie is a regular user of Twitter (https://twitter. com/cjsavoie) and uses his account to post articles in English and Japanese about parental child abduction. He also uses it to convey messages to his children and ex-wife in Japan (although whether they ever see them is unknown). Then there are some more lateral approaches to the use of social media in parental child abduction cases. For example, a Twitter account in the name of Ashleigh Mojica Laws, (https://twitter.com/ashleighmojica), aged 1, appeared just a few months after her Filipina mother failed to return her to the United Kingdom after a holiday to the Philippines (Evening Chronicle 2011; Laws 2011). The Japanese connection to this case involved an allegation made by Ashleigh's father that her mother had been encouraged to abduct the child by a Japanese friend, as per the "Japanese playbook" on abduction (The Japan Children's Rights Network, n.d.[b]). Ashleigh is described in her Twitter profile as a "victim of international parental child abduction". The activity on the account was short-lived, but the creation of a social media account in the name of a baby who has no autonomy could be an attempt to garner sympathy for her father, either by himself or by a third party on his behalf.

The public forums provided by sites such as The Japan Children's Rights Network website provide a mechanism for left-behind parents to tell their stories and act as a conduit for information between left-behind parents and their children. They also have a coercive effect on the parent retaining the child; that is, they provide a kind of virtual bargaining chip for left-behind parents. By posting stories of parental child abduction and pictures of abducted children and their abducting parent, these sites act as an extra-legal form of pressure on abducting parents. The Japan Children's Rights Network details international and domestic abduction cases in which the abducting parent has contacted the organisation to request that information be removed, and where contact has been restored between the left-behind parent and their child on condition that the information is removed from the site (The Japan Children's Rights Network n.d.[d]). The very nature of these cases means there is a lack of identifying details. This is a clear example of the power of social media to-wrongly or rightly-name and shame, and feeds into its use as a type of virtual scarlet letter. Such usage has come to academic (e.g., Solove 2007) and popular (e.g., Ronson 2015) attention in recent years.

While those parents and supporters advocating for change to the way parental abduction is handled in Japan are clearly visible in social media, there are other individuals and groups who advise caution in changing Japan's approach to custody disputes. Some groups in opposition to Japan joining the Hague Abduction Convention took to social media prior to Japan eventually joining the treaty in 2014. One of these groups is the Safety Network for Guardians 
and Children (ハーグ条約加盟に反対する会), which set up its website in 2011 (Safety Network for Guardians and Children 2012). Another group of this kind is Hāgu 'ko no dasshu' jōyaku no hijun ni shinchō na kentō o motomeru shimin to hōritsuka no kai (ハーグ「子の奪取」条約の批准に慎重な検討を 求める市民と法律家の会; 'Association of Citizens and Lawyers Requesting Careful Consideration with Respect to the Ratification of the Hague 'Child Abduction' Convention') (Hāgu 2011). Both groups set out to register their concern regarding the signing of the Hague Abduction Convention by Japan, particularly with respect to the treatment of victims of family violence under the treaty. This concern echoes a large body of work in western legal theory which criticises the Hague Abduction Convention for not taking due account of the risks posed to abused spouses (e.g., Kaye 1999; Weiner 2004; Shetty and Edleson 2005).

Individual parents who have abducted their children have also used social media to tell their stories and explain their actions. Mika Yamashita is a Japanese citizen who started a blog under the name 'Marinko' in 2008 about her marriage to an Australian man in Australia, and their divorce and subsequent protracted custody dispute over their three daughters under Australian law. ${ }^{8}$ She ultimately abducted the children from Australia to Japan in February 2009. Her blog was eventually published as a book in Japan in 2010 (私が誘拐犯になるまで; 'I was Driven to Abduction') (Yamashita 2010). On the blog, and eventually in her book, Yamashita writes of her feelings of isolation while in Australia, her ex-husband's abusive and threatening behaviour and her frustration with the Australian legal process. Importantly, she also writes of her shock at the concept of shared parental authority under Australian law which meant she was essentially tied her to ex-husband until the children reached adulthood (Yamashita 2010, 59).

The staking out of moral territory on the internet by groups and individuals on both sides of the issue highlights the complexity of this social, legal and political problem and the careful attention required when analysing social media sites with respect to this sensitive issue.

\section{The Significance of the Use of Social Media in Parental Child Abduction Cases}

The use of social media in these cases is important for a number of reasons. Firstly, it provides a common thread for left-behind parents to communicate with each other. While some left-behind parents have the capacity to attract mainstream media attention to their cases, the overwhelming majority (should they wish to) do not, but the chances that they have access to some form of social media are far greater. ${ }^{9}$ In this way, social media is a leveller and community builder. It also creates a virtual support group for disparate parents whose paths may not have otherwise crossed due to restrictions on time and travel. 
Secondly, social media is important in these cases due to their dynamic nature. While a left-behind parent may have exhausted their legal options, their story does not end there. Many will feel compelled to keep agitating for their cause and looking to reach out to their lost children. Social media is a vital mechanism for documenting these ongoing stories. This idea was eloquently summed up by Scottish left-behind parent Douglas Galbraith, whose two sons were abducted from the United Kingdom to Japan by his Japanese wife. Douglas, an author, wrote a book entitled My Son, My Son: How One Generation Hurts the Next [2013] about his experience of the abduction, and likened his book to a "message in a bottle" to his children (Ross 2012, par. 6). Being unable to communicate with his sons, he felt his book was one way of potentially completing a "wide blank" in their lives at a later date and possibly correcting other versions of the story they may have been told by their mother (Ross 2012, par. 6). Not everyone has the resources and abilities to pen a publishable commercial manuscript, but social media allows most parents to try to fill the "wide blank" left by abduction for their children. The use of social media sites, including genealogy websites, has resulted in a "staggering number" of reunions between parents and children after years apart in abduction cases worldwide (Dabbagh 2012, 140).

The idea of social media providing a virtual "message in a bottle" proved true in the dramatic case of Chris Gulbraa. In August 2006 at the age of 15, Chris returned to his American father, Michael Gulbraa, in Utah after being taken to Japan from his home by his Japanese mother, Etsuko Tanizaki Allred, five years earlier (Brown 2006). Chris and his brother, also named Michael, were abducted to Japan by their mother on 28 November 2001. The couple had been divorced for several years prior to that time and Etsuko had custody of the children. The elder Michael had taken out a temporary restraining order requiring the children to remain in Utah after becoming concerned for their safety in the care of Etsuko's new husband (Brown 2006). The order was still in place at the time of the abduction (Gulbraa 2009). The father was awarded custody of the boys in April 2002 (Brown 2006). Chris claims that after he had been taken to Japan, his mother discouraged him from contacting his father, but he was given a mobile telephone after he turned 15 , which he used to send text messages to his father. On the last day of the summer holidays in 2006, Chris took a train from Kasugai to Osaka, where he went to the U.S. Embassy and was provided with documents allowing him to return to the United States, which had been arranged in advance by his father (Brown 2006). The case was heavily documented by the Japan Children's Rights Network website and other internet sites. In particular, the Japan Children's Rights Network site provided the father with a space to provide a detailed account of his story, accompanying which he posted a large number of legal documents regarding the custody of his sons (The Japan Children's Rights Network n.d.[c]). While the father was reluctant to disclose the precise details of how Chris was recovered to the United States, he reported that the internet documentation played a significant role in the recovery (The Japan Children's Rights Network n.d.[d]). 


\section{DIVISIONS WITHIN DIVISIONS: JAPANESE FAMILY LAW}

As noted in the introduction to this article, custody laws in Japan are being outpaced by changes in society arising from the creation and dissolution of international families, and social media is utilised by concerned parties as a way of bridging the gap. In this section, I examine the legal framework in Japan that forms much of the background and the impetus for this social media activity.

Japanese family law is contained in Book 4 ("Relatives") and Book 5 ("Inheritance") of the Civil Code (民法). While the family law provisions of Japan's Civil Code are predominantly modelled on French law, the historical legal system known as ritsuryō (律令) in Japan, which has its roots in Chinese legalism and Confucian ideals, has also been highly influential in the Japanese understanding of the function of law (Mizuno 2014, 254). Under the ritsuryo system, the law's function is to facilitate administrative policy, rather than to delineate the limits of authority; that is, it provides a less-prescriptive system of law than is seen in the west, which limits the rights and obligations that may be imposed on citizens (Mizuno 2014, 254). In family law, the ritsuryō concept may be seen in the ability of citizens to execute personal changes in status administratively, most notably through the family registration system, known as the koseki seido (戸籍制度) (Mizuno 2014, 259). ${ }^{10}$

While the overall marriage rate in Japan has declined and the age of marriage has risen in Japan since the 1970s (Ministry of Health, Labor and Welfare 2015, Table 9.1; Piotrowski et al. 2015, 1042), Japan remains a society in which formal legal or de jure marriage is the norm. De facto unions are still rare (Piotrowski et al. 2015, 1042) and the rate of births out of wedlock is extremely low, representing only $2.3 \%$ of the total of live births in Japan in 2014 (Ministry of Health, Labor and Welfare n.d., 33). The rate of births outside wedlock was similar in South Korea for 2014 (1.9\%), but very low compared to $40.3 \%$ in the United States in the same year (Ministry of Health, Labor and Welfare n.d., 33). The rate in the Philippines was also much higher than Japan in the same period, at 50.3\% (Philippines Statistics Authority 2016).

Japanese family law imposes divisions after family breakdowns that often exclude the parent who does not reside with the child. Japanese and nonJapanese parents alike have struggled with the constraints of the Japanese family law when trying to regain contact with their children and establish custodial and visitation arrangements after their children have been taken by the other parent. These constraints relate most prominently to the absolute nature of parental authority after divorce and the conceptualisation of visitation under Japanese law, both of which are discussed in detail below.

Japanese law does not recognise the concept of shared parental authority. Under its Civil Code, both parents are deemed to have shinken (親権; parental authority) over a child of the marriage until divorce, at which point it requires that either one parent or the other be designated parental authority (art. 819). 
Shinken includes the power to make decisions about the child's care, education and place of residence, as well as to represent the child in a legal sense, such as entering into contracts on the child's behalf (arts. 820, 821 and 824). From this broad pool of shinken powers, it is possible to separate physical custody, called kangoken (看護権), which encompasses the power to make decisions regarding the child's care, residence and education, from legal custody (still called shinken in this more limited, residual sense), which entails the power to enter into contracts, manage inheritances and dispose of real property in the child's name. In this way, upon divorce each parent can be vested with one of these two types of custodial authority (Bengoshi höjin 2014, 174). Even so, actual cases where custody is split in this way are rare in Japan. According to the Annual Report of Judicial Statistics (司法統計年報) compiled by the Supreme Court of Japan, out of the 18,246 cases in which the mother was allocated shinken by way of mediation or judgement in 2014, only 36 cases also involved a designation of kangoken to the father (Supreme Court of Japan $2014,43)$. Out of the 2,002 cases in which the father was allocated shinken that year, only 122 also involved a designation of kangoken to the mother (Supreme Court of Japan 2014, 43). The mechanism of splitting kangoken from the broader pool of shinken powers may be regarded as a function of pre-war law, under which it was sometimes considered appropriate to allow mothers to continue to physically provide care for children after divorce, even though there was a preference for granting legal custody to fathers and continuing the formal patrilineal relationship (Jones 2007, 216).

The Japanese system of family law, which designates sole parental authority to one parent or the other upon divorce, can be viewed as intrinsically tied to the koseki seido (family registration system). The koseki seido is historically linked to the 'household system', or ie seido (家制度), which is characterised by stemfamily relations and the value ascribed to lineage, and is widely considered to have its origins in feudal traditions and Confucian values of filial piety (see White 2002; Ronald and Alexy 2011). The koseki seido also plays a key role in defining one's self as Japanese. It was a precursor to the modern legal definition of nationality and was the sole mechanism of establishing legal status as Japanese until the introduction of the Nationality Law (国籍法) in 1899. Today, in the majority of cases it is not possible to establish Japanese nationality without a family record, or koseki (戸籍) (Chapman 2011). Noncitizens cannot register their own koseki. Japanese registrants tend to attach subjective meaning to their formal, administrative family as set out in their koseki, even where there may be a dislocation between the dynamics of the registered family and its social reality (Krogness 2011, 65). This attachment is an important consideration when analysing the issue of international parental child abduction in Japan from a social, political and legal perspective: children of Japanese citizens are viewed as belonging to a Japanese family's koseki, and the parent who retains shinken with respect to the child after divorce (whether inclusive of kangoken or not) retains the right to include the child in their koseki. This arguably creates a symbolic barrier to the idea of shared custody or custody by the non-Japanese spouse in the case of a breakdown in an international marriage. 
While the custom of the father taking custody after divorce continued up until the mid-1960s, there is now a well-entrenched maternal preference in child custody cases (Fuess 2004, 156-57; Costa 2010, 378). This reflects a transition from concern with patrilineal integrity to a focus on the 'best interests of the child'. Mothers were granted custody in $92.5 \%$ of cases handled by family courts in Japan in 2014 (Supreme Court 2014, 43); this figure is indicative of how custody has been awarded in divorce cases over the past 50 years, as the rate of paternal custody has not altered significantly during that time (Bengoshi Hōjin 2014, 177). This means it is fathers who most often lose all rights of custody upon divorce.

The predominance of sole custody in Japan brings the issue of visitation into stark relief. While some divorce handbooks ${ }^{11}$ published in Japan describe the non-custodial parent as having a “visitation right” (面接交渉権) (e.g., Baba Sawada 2008, 61; Hiruta 2012, 92; Hiruta 2014, 106), whether the concept holds any legal weight has been a matter of debate for many years (Jones 2007, 240-45; Kojima 2011, 90-102; Tsuneoka 2013, 57-58). In any event, Japanese statute does not explicitly recognise visitation as a legal right (Jones 2007, 228-29). From 1 April 2012, an amendment to Article 766 of the Civil Code took effect which requires couples divorcing by kyogi rikon to state their agreement on visitation and other contact, child support payments and other matters concerning the care of the child on their divorce application. This amendment represents the first time that post-divorce visitation or other interaction between a child and their non-custodial parent has been referred to in Japanese statute (Jones 2011b). Its effect has been limited, however, as failure to comply with the requirements set out in Article 766 does not attract any penalty, nor is it a barrier to obtaining a divorce (Hiruta 2014, 106). The non-government organisation Kizuna Child-Parent Reunion reports that compliance with Article 766 is as low as 50\% (Kitagawa 2014). Separately, in March 2013, the Japanese Supreme Court found that a court could impose a fine on a custodial parent who failed to facilitate visitation when required to do so by a court order or arbitrated decision. ${ }^{12}$ The fine for this kind of case is relatively small: JPY50,000 (approximately AU\$500) (Supreme Court of Japan 2013). While this may be a sign of progress for non-custodial parents involved in the small percentage of mediated and adjudicated cases, it is nonetheless only an indirect form of enforcement of visitation determinations, and noncompliant parents may simply pay the fine as a form of 'efficient breach' (Goetz and Scott 1977) to maintain distance from the other parent.

Accordingly, for the majority of parents without shinken, the law effectively prevents them from having a major presence in their children's lives; they become an "optional part" of their family (Jones 2007, 221). This plays out in reality as a so-called 'clean break', where a child and their custodial parent

\footnotetext{
11 Divorce handbooks are self-help guides that are generally written by lawyers or legal scholars for popular consumption and sold in major bookshops. They typically contain basic explanations of laws relating to divorce, asset division and custody, practical information regarding the divorce process, advice on post-divorce life and information regarding the impact of divorce on the parties' koseki. Example titles of these types of handbooks are ‘Easy to Understand! Divorce Procedure and Process’ [よくわかる! 離婚の手続きとすすめ方] (Hiruta 2012) and 'Life's Legal Issues Series: I Want to Ask a Lawyer! Divorce and Children Issues Q\&A' [暮らしの法律問題シ リーズ 弁護士にききたい! 離婚と子どもの問題] (Baba Sawada 2008).

12 In Japanese, the case name is Kansetsu kyōsei ni taisuru shikkō kōkoku kikyaku kettei ni taisuru kyoka kōkoku jiken (間接強制に対する執行抗告棄却決定に対する許可抗告事件), which translates as 'Permitted Appeal of the Dismissal of an Appeal for the Execution of Indirect Enforcement.'
} 
have no contact with the non-resident parent. While this is certainly not a rule, it is a kind of social norm in Japan and stands in marked contrast to the family law systems of many other countries around the world in which the concepts of shared parental authority and the nurturing of the parent-child bond in the event of a family breakdown have emerged as vital tenets. These countries include some of Japan's treaty partners under the Hague Abduction Convention, such as the United States of America, Australia, the United Kingdom, Canada, the Scandinavian countries and Germany (see Rhoades 2002; Ryrstedt 2003; Tanase 2011). The concept of shared parental authority is, however, by no means universal, nor is it consistently applied (for further discussion see Blair and Weiner 2005).

The Japanese family law system, like many other family law systems around the world, ${ }^{13}$ places importance on maintaining the status quo of a child's living arrangements despite a family breakdown. Given the absolute nature of the custody law, it is critical for a parent wishing to be awarded custody under Japanese law to first establish a pattern of caring for the child (Bengoshi Hōjin 2014, 176-77). In combination with the maternal preference, the risk faced by fathers under the status quo preference is clear should the mother take the child. One divorce handbook even goes so far as to suggest that fathers ask their own parents to stay at the family home to watch the mother, and also advises them to speak to the staff at the child's childcare facility to warn them of the risk of abduction (Bengoshi Hōjin 2014, 177-79).

Until the ratification of the Hague Abduction Convention, custody orders issued outside Japan were not likely to assist a left-behind parent in navigating their way through the constraints of the Japanese legal system in the case of parental abduction. While Japanese courts can and have recognised foreign custody orders, ${ }^{14}$ they are often not enforced (Jones 2007, 256-57). This may be a reflection of the practical and logistical difficulties associated with enforcement of international custody orders, but it is also due to the lack of legal measures available against non-compliant parties and the reluctance of the police to become involved in domestic disputes (Jones 2007, 256-57). A preference for the status quo may also play a part. The effect is that even parents with full custody of their child under a foreign law may have little or no parenting authority under Japanese family law after their child has been taken to Japan by the other parent (Jones 2007, 256-57).

\footnotetext{
13 The likely effect of changing a child's circumstances is a factor to be considered alongside other factors by courts determining matters involving the upbringing of a child under UK family law (Children Act 1989, Section 1(3)(c)); for further discussion see Lowe and Douglas 2015, 409-10). A long-standing status quo arrangement is often a significant factor in custody determinations by state courts in the United States, for example in California (see Row 2015, $\$ 1.31$; Waller 2008, 108). In Australia, it is an "additional consideration" (as opposed to a "primary consideration") to which courts must have regard (The Family Law Act 1985; Section 60CC (3)(d); for further discussion see Rathus and Alexander 2014, 383-84). The status quo is a consideration in all of these jurisdictions, but its significance is consistently subject to the paramount consideration of the best interests (as expressed under Australian and Californian law) or welfare (as expressed under U.K. law) of the child. Japanese courts also apply a "best interests of the child" standard (see Jones 2007), highlighting the complex nature of this seemingly simple concept.

14 Japan's statute on conflict of laws or private international law rules, Hō no tekiyō ni kansuru tsūsoku hō (法 の適用に関する通則法; Act on the General Rules of Application of Laws), provides that the legal relationship between a parent and a child is to be determined by the child's national law where that is the same as the national law of either the father or mother's national law, or in all other cases by the law of the child's habitual residence (art. 32). The Act also provides that where a person has two or more nationalities, his or her national law shall be the country in which the person has habitual residence from among those states of which he or she has nationality, or if there is no such country, the law of the state with which he or she is most closely connected. Where one of those nationalities is Japanese, Japanese law shall be that person's national law (art. 38).
} 
These elements of the Japanese domestic law combine to create an environment in which some parents feel like they have no options but to turn to abduction. ${ }^{15}$ Very little incentive is provided under the law for custodial parents to encourage or facilitate contact with the non-resident parent. By disproportionately and absolutely favouring those parents with residence of their children, regardless of how those living arrangements came about, the Japanese legal system is open to being criticised for allowing custody disputes to become a "zero sum game” (Jones 2014) or a case of “whoever abducts first wins” (先に連れて行っ たもの勝ち) (Bengoshi Hōjin 2014, 177). In such an environment, it seems only natural that the 'losing' party will seek some form of redress through extralegal forums when their legal avenues have been exhausted.

\section{Engagement with International Law}

Until recently, the difficulties faced by left-behind parents within the Japanese legal system were compounded by the fact that Japan was not a party to the Hague Abduction Convention, which is the key mechanism at international law dealing with the issue of international parental child abduction. The Hague Abduction Convention calls for the restoration of the pre-abduction status of the child, with a view to having the issues of any substantive custody dispute determined by a court in the child's place of habitual residence in accordance with its local laws (art. 1). Habitual residence is a legal concept determined by reference to indicia such as shared parental intent and the experiences of the child up to the point of the abduction (see Vivatvaraphol 2009). Without the Hague Abduction Convention, and in the absence of any other international agreement on international child abduction, left-behind parents can only try to assert their right of custody through the domestic legal system of the country to which their child has been taken. For the reasons discussed above, left-behind parents of children residing in Japan have often faced insurmountable difficulties when trying to assert rights of custody, including visitation, under the domestic legal system.

The Hague Abduction Convention was first drafted by the Hague Conference on Private International Law on 24 October 1980 and put out for ratification over 30 years ago. All G7 nations, with the exception of Japan, had ratified the Hague Abduction Convention by 1995 (Hague Conference on Private International Law 2014). This omission on the part of Japan was widely reported in the English-language media both inside and outside of Japan (e.g., The Mainichi 2013; McCurry 2008; Sekine 2013). Japan's neighbours Thailand, Singapore, Russia and South Korea ratified the Hague Abduction Convention in 2002, 2010, 2011 and 2012 respectively (Hague Conference 2014). The Hague Abduction Convention also applies in the Special Administrative Regions of Hong Kong and Macau, entering into force there in 1997 and 1999 respectively (Hague Conference 2014). The People's Republic of China and the Philippines,

15 There are no statistics on the number of domestic parental child abductions in Japan. The Supreme Court of Japan acknowledges that a portion of the applications made in Japanese family courts each year for the handover (引渡し) of children are cases of parental abduction (Supreme Court of Japan 2005; see also Jones (2011a)). Jones notes that the hand-over disputes which reach court represent only a small number of the overall disputes each year (2011a, 51). In 2014, the Japanese family courts handled a total of 2,074 applications for the hand-over 
however, are not signatories to the Hague Abduction Convention which is of significance given the high number of marriages between nationals of Japan and these two countries.

In May 2011, the government of Japan announced its intention to join the Hague Abduction Convention, and signed and ratified the treaty on 24 January 2014. The Hague Abduction Convention entered into force in Japan on 1 April 2014, and legislation governing its implementation took effect the same day. ${ }^{16}$

\section{EMERGING TENSIONS IN JAPANESE CASES}

The Japanese Ministry of Foreign Affairs is considering the implementation of the Hague Abduction Convention a success so far, noting a drop in reported abductions between 2013 and 2014 (Masangkay 2015). While the signing of the treaty was a significant step towards legal, social and cultural change for Japan, some commentators have been subdued in their assessment of developments to date, including U.S. Congressman Christopher Smith, who is a vocal advocate for American left-behind parents and believes Japan has been too slow in responding to international abduction cases (Slavin 2015).

Japan returned its first child under the Hague Abduction Convention in October 2014. In that case, the boy's Japanese mother had taken the child to Japan from his home in Germany in June 2014 without the consent of his German father. After the father made an application for the return of the child under the Hague Abduction Convention, the Japanese Ministry of Foreign Affairs was able to mediate an agreement between the parties for the return of the child.

The much-anticipated first ruling by a Japanese Court with respect to a return application under the Hague Abduction Convention was made on 19 November 2014. The case involved a Japanese couple and their four-year-old daughter who had been living in Sri Lanka since February 2013. The mother had taken the child to Japan for a temporary visit in June 2014 and failed to return to Sri Lanka. The father's return application was heard by Chief Justice Shinichi Oshima of the Osaka Family Court, who ruled that the daughter be returned to Sri Lanka (Abe 2014). The mother appealed the ruling to the Osaka High Court but it upheld the lower court's decision on 30 January 2015 and the child returned to Sri Lanka in April 2015 (Ito 2015). In March 2015, the first application under the Hague Abduction Convention concerning an international union, that is one involving a non-Japanese parent, came for judicial ruling before a Japanese court. In that case, the Japanese mother had married the Turkish father in Turkey and had continued to live there after the birth of their child. The mother returned to Japan with the child in December 2014, prompting the father to make an application for the child's return under the Hague Abduction Convention. On 20 March 2015, the Tokyo 
Family Court ordered that the child be returned to Turkey (The Mainichi 2015). These rulings are historically and legally important as they represent the first rulings under the Hague Abduction Convention in Japanese courts, include an appellate court. They are also culturally and politically significant, as they demonstrate that the Hague Abduction Convention can be effectively implemented in Japan, and they could be construed as the first steps in dismantling its reputation as a "black hole" for parental abductions.

No official figures have been published by the Japanese government regarding the number of cases addressed since the Hague Abduction Convention was implemented, so it is difficult to make an objective assessment of its effectiveness so far. It does seem, however, that a major source of discontent for left-behind parents has arisen in the way that applications for visitation under the Hague Abduction Convention are managed by Japan. According to a report in The Japan Times, Japan received 86 applications for visitation under the Hague Abduction Convention from April 2014 to August 2015 (Kameda 2015). Of these, 67 were in relation to children removed to or retained in Japan (Kameda 2015). In response to applications for visitation, Japan announced it would implement a system of visitation via video conferencing to address applications for visitation under the Hague Abduction Convention (Kameda 2015). These video conferences would be monitored by an independent social worker who has the authority to intervene if they deem it necessary to do so (Kameda 2015). The Japanese branch of the Geneva-based non-governmental organisation International Social Service is contracted by Japan's Ministry of Foreign Affairs to provide the independent social workers to facilitate such visitation under the Hague Abduction Convention (International Social Service Japan, n.d.).

'Virtual visitation' is not a new concept. It has been ordered in child custody cases around the world since the late 1990s (Knoetze 2013) and it does seem a positive move towards the use of new media to link people in different countries. The use of an independent third-party monitor as standard, however, is a concept novel to Japan. While this is better than having no visitation at all, this type of limited and monitored contact is regarded as unnecessarily punitive and suggestive of wrongdoing by some left-behind parents (Masangkay 2015). Such critics have pointed out that supervised access is typically ordered in western legal systems in cases of family violence or where the visiting parent has problems with substance abuse or mental illness (Masangkay 2015). Its use in situations where abduction is a risk is, however, also well established in both western legal systems and in Japan (e.g. Pearson and Thoennes 2000; Hiruta 2012, 92; Kajimura 2013, 248-51). The tyranny of distance in international custody cases means that parents may have to adjust their understanding of what counts as a visit with their child and accept the assistance offered by technology. Nevertheless, the value of this type of access must be questioned when it does not promote genuine communication between the parent and the child and is not supplemented by physical meetings (see Doucet 2011). 
The issue with respect to virtual visitation may be seen as an extension of the existing problem of dislocation between the nature of visitation as it is understood in Japan and how it is recognised in many other countries. Visitation, when ordered or agreed upon in Japan, tends to be 'minimalist'; that is, of relatively short duration (no more than two or three hours) and limited in frequency (monthly or bimonthly), and in contentious cases may involve only a formal meeting at a designated family centre (Tanase 2011, 579-80). ${ }^{17}$ This virtual visitation issue is also indicative of the wider challenges faced by Japan in navigating the lingering tension between its domestic family law and the more liberal approaches to custody and visitation of many of the other Hague contracting states. ${ }^{18}$ This unresolved tension means that many left-behind parents are disappointed with the outcomes they receive through the legal options available to them. For many, social media provides an opportunity for the expression of this disappointment, and the search for solace and some form of resolution.

\section{CONCLUSION}

Social media platforms such as Skype and Facebook provide a readily accessible means of communication to support the honeymoon phase of new long-distance relationships, and help established families maintain ties across great distances and national borders. Social media can, however, also support and document the disruption of relationships. My examination of the use of social media in cases of parental child abduction can perhaps be seen in part as belonging to this flipside: it is technology acting to support the downside of international relationships.

In his fictional critique of social media networks, The Circle (2013), author Dave Eggers discusses the "communion" found by those publicly documenting their painful experiences. While the intense bereavement felt by left-behind parents at the loss of their relationships with their children cannot be understated, social media can have a positive effect in these cases by bringing people with common issues together and potentially allowing parents to reconnect with children who have been abducted or are otherwise lost in another country, even though it may be many years later. It is one manifestation of a "virtual community" (Castells 2001, 386-89) which has arisen from the greater distribution of communications technology for public use.

Japan is at an important moment in its family law history as it increases its connection to international family law through its implementation of the Hague Abduction Convention, as seen in the first cases heard under the treaty in Japan. The wider impact of these developments on Japan's domestic law, and its attitude to cases which do not fall under the Hague Abduction

\footnotetext{
17 In divorce cases determined in 2014 by family courts in Japan (by way of mediation or adjudication), weekly and fortnightly visitation was provided for in approximately $7.1 \%$ and $8.1 \%$ of cases respectively; monthly visitation was provided for in approximately $43.5 \%$ of cases; and overnight visitation was agreed upon or ordered in approximately $7.1 \%$ of cases (Supreme Court of Japan 2014, 43). 
Convention, is yet to be seen. For now, social media is used by individuals affected by international custody disputes to reach out to others and seek assistance, whether as a left-behind parent, an abducting parent or a parent concerned about the potential for abduction in the future. This is important in the case of abductions involving Japan, given the dislocation between its family law and the varying expectations held by parents involved in abduction cases as to the way the custody of their children ought to be managed. This dislocation is not limited to international cases, with Japanese parents also expressing disillusionment at the state of the law in Japan governing domestic custody cases. By connecting these groups, social media facilitates a subtle but substantive form of internationalised communications.

While much of the content produced and shared via social media may seem prosaic, in the case of international parental child abduction, it allows a disparate group of people with a specific and urgent issue to locate each other, subject to internet access around the world, and work together to share information, seek and provide support, and move toward solving their specific issues. In this way, social media helps to fill a void left by a legal system which has not yet adapted to meet the needs of a changing and internationalised form of family. It can provide a light for parents in an otherwise intractable situation. Whether social media will continue to play this role depends in large part on the way in which Japanese law and society responds to new conditions of the family in society.

\section{GLOSSARY}

chōtei (調停)

mediation

hikiwatashi (引渡し)

hand-over (of children to the legally recognised custodial parent)

ie seido (家制度)

household system, characterised by stem-family relations and the value ascribed to lineage, and widely considered to have its origins in feudal traditions and Confucian values of filial piety

\section{kangoken (監護権)}

physical custody

kokuseki hō (国籍法)

Nationality Law

koseki (戸籍)

family record

koseki seido (戸籍制度)

family registration system

divorce by consent 
mensetsu kōshōken (面接交渉権)

visitation right (lit., 'visitation negotiation right')

$\operatorname{minp} \bar{o}$ (民法)

Civil Code

ritsuryō (律令)

system of codification of criminal and administrative/civil law with origins in Chinese legalism and Confucian ideals

shinken (親権)

parental authority; also, legal custody (as opposed to physical custody)

shihō tōkei nenpō (司法統計年報)

Annual Report of Judicial Statistics compiled by the Supreme Court of Japan

\section{APPENDIX: LIST OF RELEVANT LAWS/TREATIES AND ADVOCACY GROUP WEBSITES}

\section{Laws/Treaties}

Act for Implementation of the Convention on the Civil Aspects of International Child Abduction [国際的な子の奪取の民事上の側面に関する条約の実施に関する法 律], act no. 48 of 2013

http://www.japaneselawtranslation.go.jp/law/detail/?id=2159\&vm $=04 \& \mathrm{re}=01$ (Japanese and provisional English translation)

Act on the General Rules of Application of Laws [法の適用に関する通則法], act no. 10 of 1898

http://law.e-gov.go.jp/htmldata/H18/H18HO078.html (Japanese)

https://sydney.edu.au/law/anjel/documents/ZJapanR/ZJapanR23/ZJapanR23_20B_ Okuda_Anderson_Translation.pdf. (English)

Civil Code (Japan) [民法], act no. 89 of 1896

http://www.moj.go.jp/content/000056024.pdf (Japanese and English)

Convention of 25 October 1980 on the Civil Aspects of International Child Abduction https://assets.hcch.net/docs/e86d9f72-dc8d-46f3-b3bf-e102911c8532.pdf

Nationality Law (Japan) [国籍法], act no. 147 of 1950

http://www.moj.go.jp/MINJI/kokusekiho.html (Japanese)

http://www.moj.go.jp/ENGLISH/information/tnl-01.html (English)

\section{Advocacy Group Websites}

Chūbu kyōdōshinken hōseika undō no kai [中部共同親権法制化運動の会]

Chubu Joint Custody Association for Legislating of Joint Custody and Joint Nurture http://chubu-kyoudousinken.com/

Hāgu jōyaku kamei ni hantaisuru kai [ハーグ条約加盟に反対する会] 
Hāgu 'ko no dasshu' jōyaku no hijun ni shinchō na kentō o motomeru shimin to hōritsuka no kai [ハーグ「子の奪取」条約の批准に慎重な検討を求める市民と法律家の会] Association of Citizens and Lawyers Requesting Careful Consideration with Respect to the Ratification of the Hague 'Child Abduction' Convention

http://hague-shincho.com/

Kyōdōshinken undō nettowāku [共同親権運動ネットワーク] or K-netto [Kネット]

'Joint Custody Action Network (K-net)'

http://kyodosinken.com/

Left Behind Parents Japan

http://www.meetup.com/Left-Behind-Parents-Japan/

The Japan Children's Rights Network (CRN Japan)

http://crnjapan.net/The_Japan_Childrens_Rights_Network/Welcome.html

\section{REFERENCES}

Abe, S. 2014. "Osaka Court Orders Return of Child to Sri Lanka under the Hague Treaty," The Asahi Shimbun (Asia \& Japan Watch), 20 November. Accessed 15 February, 2016. http://ajw.asahi.com/article/behind_news/social_affairs/AJ2 01411200052 .

Act on the General Rules of Application of Laws [法の適用に関する通則法], act no. 10 of 1898. English translation by K. Anderson and Y. Okuda. Accessed 19 May, 2016. https://sydney.edu.au/law/anjel/documents/ZJapanR/ ZJapanR23/ZJapanR23_20B_Okuda_Anderson_Translation.pdf.

Agopian, M. W. 1984. "The Impact on Children of Abduction by Parents." Child Welfare 63 (6): 511-19.

Akeo, M. 2010. "Point of View/Masako Akeo: Japanese Laws Should Encourage Joint Custody," The Asahi Shimbun, 23 June. Accessed 28 February, 2014. http:// www.asahi.com/English/TKY201006220385.html.

Åkerström, M. 2015. "Deliberation and Adjudication as Democratic Practice in Post-fact Society." In Strategic Communication, Social Media and Democracy: The Challenge of the Digital Naturals, edited by W. T. Coombs, J. Falkheimer, M. Heide and P. Young, 119-29. Oxford: Routledge.

Austin, M. 2013. "Rights and Obligations of Parents." Internet Encyclopaedia of Philosophy. Accessed 30 December, 2014. http://www.iep.utm.edu/parentri/.

Australian Bureau of Statistics. 2015. "Table 10, Children Aged 0-17 Years with a Natural Parent Living Elsewhere, Contact Arrangements by Age of Child 2012-2013, 2009-2010, 2006-2007," 4442.0-Family Characteristics and Transitions, Australia, 2012-2013. Accessed 14 February, 2016. http:// www.abs.gov.au/AUSSTATS/abs@.nsf/DetailsPage/4442.0201213 ?OpenDocument. 
Australians with Abducted Children. 2013. "About Us." Australians with Abducted Children. Accessed 24 June 2016. http://www.awac.asn.au/Australians_ With_Abducted_Children/About_Us.html.

Baba Sawada Hōritsu Jimusho [馬場・澤田事務所]. 2008. Kurashi no hōritsu mondai shiriizu Bengoshi ni kikitai! Rikon to kodomo no mondai QઐA [暮らしの] 法律問題シリーズ 弁護士にききたい! 離婚と子どもの問題Q\&A]. Tokyo:Chūō Keizaisha [中央経済社].

Bengoshi Hōjin Mai Taun Hōritsu Jimusho [弁護士法人マイタウン法律事務所]. 2014. Otoko no rikonjutsu, bengoshi ga oshieru 'katsutame' no rikon senryaku [男 の離婚術、弁護士が教える「勝つため」の離婚戦略]. Tokyo: Kōdansha [講談社].

Birmingham, L. 2011. "How Did Japan Become a Haven for Child Abductions?" Time, 7 March. Accessed 4 February, 2016. http://content.time.com/time/ world/article/0,8599,2056454,00.html.

Blair, D. M. and M. H. Weiner. 2005. "Resolving Parental Custody Disputes-A Comparative Exploration.” Family Law Quarterly 39 (2): 247-66.

Bodenheimer, B. M. 1977. "The International Kidnapping of Children: The United States Approach." Family Law Quarterly 11 (1): 83-100.

Bramham, D. 2013. "Japan is a Black Hole for Abducted Children," The Vancouver Sun, 17 August. Accessed 14 February, 2016. http://www.vancouversun. com/life/Daphne+Bramham+Japan+black+hole+abducted+childr en/8799583/story.html

Breaden, J. and C. S. Stevens. 2014. "Introduction: Internationalising Japan as a Discourse and Practice." In Internationalising Japan: Discourse and Practice, edited by J. Breaden, S. Steele and C. S. Stevens, 1-12. London: Routledge.

Brown, K. 2006. “International Dispute Splits Up Utah Family," The Salt Lake Tribune, 25 December. Accessed 24 October, 2015.http://www.sltrib.com/ci_4898084.

Buckland, K. 2006. “Think of the Children: Japan's Prejudiced Legal System Encourages Desperate Parents to Abduct their Own Kids." Metropolis Magazine, 27 January. Accessed 24 October, 2015. http://archive.metropolis. co.jp/tokyo/618/feature.asp.

Buerk, R. 2011. "Japan Custody Heartache for Foreign Fathers," BBC News, 6 February. Accessed 5 December, 2013. http://www.bbc.com/news/worldasia-pacific-12358440.

Castells, M. 2001. The Internet Galaxy: Reflections on the Internet, Business and Society. Oxford: Oxford University Press. http://dx.doi.org/10.1007/978-3322-89613-1

Chapman, D. 2011. "Geographies of Self and Other: Mapping Japan through the Koseki." The Asia-Pacific Journal: Japan Focus 9 (29). Accessed 19 May, 2016. http://apjjf.org/-David-Chapman/3565/article.pdf. 
Chūbu Kyōdōshinken Hōseika Undō no Kai [中部共同親権法制化運動の会]. 2016. Chūbu kyōdōshinken hōseika undō no kai, website. Accessed 14 February, 2016. http://chubu-kyoudousinken.com/.

Civil Code 1896 (Japan), act 89.

Costa, J. 2010. "If Japan Signs the Hague Convention on the Civil Aspects of International Child Abduction: Real Change or Political Maneuvering?" Oregon Review of International Law 12: 369-88.

Dabbagh, M. 2012. Parental Kidnapping in America: An Historical and Cultural Analysis. Jefferson: McFarland \& Company, Inc.

Dingle, S. 2011. "Japan Proves Safe Haven for Abducted Kids." 7.30 Report, television broadcast. Australian Broadcasting Corporation. Broadcast 7 September. http://www.abc.net.au/news/2011-09-07/japan-proves-safehaven-for-abducted-kids/2875758.

Doucet, C. 2011. “'See You on Skype!': Relocation, Access, and Virtual Parenting in the Digital Age." Canadian Journal of Family Law 27 (2): 298-50.

Eggers, D. 2013. The Circle. San Francisco: McSweeney's Publishing.

El Ouirdi, M., A. El Ouirdi, J. Segers, and E. Henderickx. 2014. "Social Media Conceptualization and Taxonomy: A Lasswellian Framework." Journal of Creative Communications 9 (2): 107-26. http://dx.doi.org/10.1177/097325 8614528608

Esin, C., M. Fathi and C. Squires. 2013. "Narrative Analysis: The Constructionist Approach." In The SAGE Handbook of Qualitative Data Analysis, edited by U. Flick, 203-16. London: Sage Publications Limited.

Evening Chronicle. 2011. "Dad's Pain after Filipino Partner Fled with Girl," Evening Chronicle, 5 July. Accessed 25 August, 2015. http://www.chroniclelive.co.uk/ news/north-east-news/dads-pain-after-filipino-partner-1401199.

The Family Law Act, 1975 (Australia), act 53.

Flyvbjerg, B. 2006. "Five Misunderstandings about Case-Study Research.” Qualitative Inquiry 12 (2): 219-45. http://dx.doi.org/10.1177/1077800405284363

Fuchs, C., K. Boersma, A. Albrechtslund, and M. Sandoval, eds. 2012. Internet and Surveillance: The Challenges of Web 2.0 and Social Media. New York: Routledge.

Fuess, H. 2004. Divorce in Japan: Family, Divorce and the State. Stanford: Stanford University Press.

Goetz, C. and R. Scott. 1977. "Liquidated Damages, Penalties, and the Just Compensation Principle: A Theory of Efficient Breach." Columbia Law Review 77: 554-94. http://dx.doi.org/10.2307/1121823

Goffman, E. 1959. The Presentation of Self in Everyday Life. Garden City, New York: Doubleday. 
Greif, G. L. and R. L. Hegar. 1993. When Parents Kidnap: The Families Behind the Headlines. New York: The Free Press.

Gulbraa, M. C. 2009. Statement (untitled) submitted to Tom Lantos Human Rights Commission Hearings on International Child Abduction, 2 December. Retrieved from Bring Abducted Children Home. Accessed 25 October, 2015. http://www.bachome.org/261/.

Hague Conference on Private International Law. 1980. "Convention on the Civil Aspects of International Child Abduction," 25 October. Recueil des Conventions: Collection of Conventions (1951-1996): 265-83.

2011. A Statistical Analysis of Applications made in 2008 under the Hague Convention of 25 October 1980 on the Civil Aspects of International Child Abduction, Part 1 Global Report. Accessed 12 February, 2016. https:/assets. hcch.net/upload/wop/abduct2011pd08ae.pdf.

. 2014. Status Table 28: Convention of 25 October 1980 on the Civil Aspects of International Child Abduction. Accessed 22 October, 2014. http://www. hcch.net/index_en.php?act=conventions.status\&cid=24.

Hāgu 'ko no dasshu' jōyaku no hijun ni shinchō na kentō o motomeru shimin to hōritsuka no kai [ハーグ「子の奪取」条約の批准に慎重な検討を求める市 民と法律家の会]. 2011. Hāgu 'ko no dasshu' jōyaku no hijun ni shinchō na kentō o motomeru shimin to hōritsuka no kai, website. Accessed 14 February, 2016. http://hague-shincho.com/.

Hargittai, E. 2007. "Whose Space? Difference among Users and Non-Users of Social Network Sites." Journal of Computer-Mediated Communication 13 (1): 27697. http://dx.doi.org/10.1111/j.1083-6101.2007.00396.x

Hiruta, K. [比留田 薰]. 2012. Yoku wakaru! Rikon no tetsuzuki to susumekata [よくわ かる! 離婚の手続きとす寸め方]. Tokyo: Shufu-no-tomo Sha [主婦の友社].

. 2014. "Rikon" no yasashii jiten: kiiwādo to yōgo de wakariyasuku kaisetsu [「離婚」のやさしい事典:キーワードと用語でわかりやすく解説]. Tokyo: Shufuno-tomo Sha [主婦の友社].

International Social Service Japan. n.d. “Contact/Visitation.” Accessed 19 May, 2016. http://www.issj.org/en/separation/contact-visitation.

Ito, M. 2015. "Girl's Return to Sri Lanka is First in Response to Hague Convention Court Order," The Japan Times, 15 April. Accessed 16 February, 2015. http:// www.japantimes.co.jp/news/2015/04/15/national/crime-legal/young-girlsent-back-sri-lanka-hague-convention/\#.VsGbTOYXV5V.

Jaffe, P. 2014. "A Presumption against Shared Parenting for Family Court Litigants." Family Court Review 52 (2): 187-92. http://dx.doi.org/10.1111/fcre.12081

The Japan Children's Rights Network. n.d.[a]. "About the Japan Children's Rights Network.” The Japan Children's Rights Network. Accessed 25 September, 2015. http://crnjapan.net/The_Japan_Childrens_Rights_Network/res-about.html. 
n.d.[b]. "Breaking News: Japanese Woman Assists Philippine Mother in Abducting her Child Using the "Japanese Playbook." The Japan Children's Rights Network. Accessed 5 December, 2013. http://www.crnjapan.net/The_ Japan_Childrens_Rights_Network/blg-anash.html.

. n.d.[c]. "'Etsuko has Ignored All Orders of the Court since October 2001...' Michael's Website." The Japan Children's Rights Network. Accessed 25 October, 2015.http://crnjapan.net/The_Japan_Childrens_Rights_Network/ per-mg.html.

. n.d.[d]. "Success Stories." The Japan Children's Rights Network. Accessed 25 October, 2015. http://crnjapan.net/The_Japan_Childrens_Rights_ Network/res-sucstore.html.

Jones, C. P. A. 2007. "In the Best Interests of the Court: What American Lawyers Need to Know about Child Custody and Visitation in Japan." Asian-Pacific Law \& Policy Journal 8: 167-69.

. 2011a. Kodomo no tsuresari mondai: nihon no shihō ga oyako o hikisaku [子どもの連れ去り問題 日本の司法が親子を引き裂く]. Tokyo: Heibonsha [平凡社].

.2011b. "Upcoming Legal Reforms: A Plus for Children or Plus Ça Change?" The Japan Times, 9 August. Accessed 1 August, 2013. http://www.japantimes. co.jp/community/2011/08/09/issues/upcoming-legal-reforms-a-plus-forchildren-or-plus-ca-change/.

. 2014. "Hague Jars with Japan's Family Law, a Zero-sum Game with Only One Outcome," The Japan Times, 16 April. Accessed 17 September, 2014. http://www.japantimes.co.jp/community/2014/04/16/issues/haguejars-with-japans-family-law-a-zero-sum-game-with-only-one-outcome/\#. VBlPjWMoVO8.

Joseph, S. 2012. "Social Media, Political Change, and Human Rights." Boston College International and Comparative Law Review 35 (1): 145-88.

Kajimura, T. 2013. Saibansho kara mita menkai kōryū chōtei, shinpan no jitsumu [裁判所から見た 面会交流調停・審判の実務]. Tokyo: Nihon Kajo Shuppan [日本加除出版].

Kameda, M. 2015. "Japan to Introduce Video Visitation System for Parents in CrossBorder Custody Disputes," The Japan Times, 28 August. Accessed 18 September, 2015. http://www.japantimes.co.jp/news/2015/08/28/national/ japan-introduce-video-visitation-system-parents-cross-border-custodydisputes/\#.ViYd4H1z9dw.

Kaye, M. 1999. "The Hague Convention and the Flight from Domestic Violence: How Women and Children are being Returned by Coach and Four." International Journal of Law, Policy and the Family 13 (2): 191-212. http:// dx.doi.org/10.1093/lawfam/13.2.191

Khondker, H. H. 2011. "Role of the New Media in the Arab Spring." Globalizations 8 (5): 675-79. http://dx.doi.org/10.1080/14747731.2011.621287 
Kitagawa, J. 2014. "Left Behind: Parents Challenge Japan's Dismal Child Abduction Laws.” Metropolis Magazine, 15 June. Accessed 30 December, 2014. http:// metropolis.co.jp/features/feature/left-behind/.

Knoetze, I. 2013. "Not So Far Apart: Virtual Visitation in Relocation Disputes." De Rebus 536: 24-25.

Kojima, I [小嶋 勇]. 2011. Hanarete mo kodomo ni aitai: hikihanasareta kodomo to no menkai kōryū o kangaeru tame ni [離れても子どもに会いたい:引き離され た子供との面会交流をかなえるために]. Tokyo: Seikatsu Shoin [生活書院].

Krogness, K. J. 2011. "The Ideal, the Deficient, and the Illogical Family: An Initial Typology of Administrative Household Units." In Home and Family in Japan: Continuity and Transformation, edited by R. Ronald and A. Alexy, 65-90. New York: Routledge.

Kyōdōshinken Undō Nettowāku [共同親権運動ネットワーク]. n.d. Kyōdōshinken undō nettowāku, website. Accessed 14 February, 2016. http://kyodosinken.com/.

Lah, K. 2009. "American Father in Custody Case Released from Japanese Jail," CNN. com, 15 October. Accessed 24 October, 2015. http://edition.cnn.com/2009/ WORLD/asiapcf/10/15/japan.custody.battle/index.html?eref=rss_ mostpopular.

Laws, A. 2011. "My Living Hell of Child Abduction," Dad's Justice Forum, 29 October. Accessed 25 August, 2015. http://dadsjustice.dadgallery.com/t89-my-livinghell-of-child-abduction.

Left Behind Parents Japan. n.d. "Left Behind Parents Japan-Home." Accessed 10 February, 2016. http://www.meetup.com/left-behind-parents-japan/.

Lowe, N. and G. Douglas. 2015. Bromley's Family Law, 11th ed. Oxford: Oxford University Press. http://dx.doi.org/10.1093/he/9780199580408.001.0001

The Mainichi. 2013. "Editorial: Gov't Must Support Japanese Nationals in Crossborder Custody Disputes," 20 February. Accessed 31 July, 2013. http:// mainichi.jp/english/english/perspectives/news/20130220p2a00m0na00 3000c.html.

. 2015. "Tokyo Family Court Orders Child to be Returned Overseas under Hague Convention," 25 March. Accessed 15 February, 2016. http://mainichi. jp/english/articles/20150325/p2a/00m/0na/012000c.

Manago, A. M., M. B. Graham, P. M. Greenfield, and G. Salimkhan. 2008. "Selfpresentation and Gender on MySpace." Journal of Applied Developmental Psychology 29 (6): 446-58. http://dx.doi.org/10.1016/j.appdev.2008.07.001

Masangkay, M. 2015. "Child Abductions Down in Year since Hague Pact but not All are Happy," The Japan Times, 2 April. Accessed 18 September, 2015. http://www.japantimes.co.jp/news/2015/04/02/national/child-abductionsyear-since-hague-pact-happy/\#.ViYfkX1z9dw. 
McCurry, J. 2008. "Family: Custody Battle in Japan Highlights Loophole in Child Abduction Cases," The Guardian, 15 September. Accessed 19 October, 2015. http://www.theguardian.com/world/2008/sep/15/japan.childprotection.

. 2013. "Japan no Longer Sanctions Child Abduction in Mixed-marriage Cases," The Christian Science Monitor, 22 May. Accessed 14 February, 2016. http://www.csmonitor.com/World/Asia-Pacific/2013/0522/Japan-nolonger-sanctions-child-abduction-in-mixed-marriage-cases.

McIntosh, J. 2009. "Legislating for Shared Parenting: Exploring some Underlying Assumptions.” Family Court Review 47 (3): 389-400. http://dx.doi.org/ 10.1111/j.1744-1617.2009.01263.x

Mégret, F. 2011. "International Human Rights Law Theory." In Research Handbook on the Theory and History of International Law, edited by A. Orakhelashvili, 199-231. Cheltenham: Edward Elgar Publishing Limited. http://dx.doi. org/10.4337/9780857933089.00016

Ministry of Health, Labor and Welfare of Japan. n.d. Vital Statistics in Japan-The Latest Trends. Accessed 19 May, 2016. http://www.mhlw.go.jp/english/ database/db-hw/dl/81-1a2en.pdf.

. 2014. Jinkō dōtai chōsa [人口動態調查]. Accessed 29 January, 2016. http:// www.mhlw.go.jp/toukei/list/81-1.html.

2015. Vital Statistics in Japan (Marriages). Accessed 15 February, 2016. http://www.e-stat.go.jp/SG1/estat/ListE.do?lid=000001137969.

Mizuno, N. 2014. "A Comparative Perspective on Japanese Family Law." In Transformation of the Public and the Intimate in Asian Modernity, edited by E. Ochiai and L. A. Hosoya, 254-65. Leiden: Koninklijke Brill NV.

Morozov, E. 2011. The Net Delusion: The Dark Side of Internet Freedom. New York: Public Affairs.

Pavlenko, A. 2007. "Autobiographic Narratives as Data in Applied Linguistics." Applied Linguistics 28 (2): 163-88. http://dx.doi.org/10.1093/applin/amm008

Pearson, J. and N. Thoennes. 2000. "Supervised Visitation: The Families and Their Experiences." Family Court Review 38 (1): 123-42. http://dx.doi. org/10.1111/j.174-1617.2000.tb00564.x

Philippines Statistics Authority. 2015. Live Births: Philippines 2014. Accessed 19 May, 2016. https://psa.gov.ph/content/live-births-philippines-2014.

Piotrowski, M., A. Kalleberg, and R. R. Rindfuss. 2015. "Contingent Work Rising: Implications for the Timing of Marriage in Japan." Journal of Marriage and Family 77 (5): 1039-56. http://dx.doi.org/10.1111/jomf.12224

Polkinghorne, D. E. 1995. "Narrative Configuration in Qualitative Analysis." International Journal of Qualitative Studies in Education 8 (1): 5-23. http:// dx.doi.org/10.1080/0951839950080103 
Postmes, T. 2007. "The Psychological Dimensions of Collective Action, Online." In The Oxford Handbook of Internet Psychology, edited by A. J. Joinson, K. Y. A. McKenna, T. Postmes and U. Reips, 165-84. Oxford: Oxford University Press.

Rathus, Z. and R. Alexander. 2014. "Goode and Goode-Judgment." In Australian Feminist Judgments: Righting and Rewriting Law, edited by H. Douglas, F. Bartlett, T. Luker and R. Hunter. Oxford: Hart Publishing Limited.

Rhoades, H. 2002. “The Rise and Rise of Shared Parenting Laws." Revue Canadienne de Droit Familial 19: 75-113.

Riessman, C. K. 2008. Narrative Methods for the Human Sciences. Thousand Oaks: Sage Publications, Inc.

Ronald, R. and A. Alexy. 2011. "Continuity and Change in Japanese Homes and Families." In Home and Family in Japan: Continuity and Transformation, edited by R. Ronald and A. Alexy, 165-84. New York: Routledge.

Ronson, J. 2015. So You've Been Publicly Shamed. New York: Penguin Group.

Ross, P. 2012. "Interview: Douglas Galbraith, Author of My Son, My Son," The Scotsman, 3 April. Accessed 25 September, 2015. http://www.scotsman. com/lifestyle/books/interview-douglas-galbraith-author-of-my-son-myson-1-2209815\#axzz3pBwV83aU.

Row, C. A. 2015. "Overview of Custody and Visitation Litigation". In California Child Custody and Litigation and Practice (April 2015 Update). Oakland: Continuing Education of the Bar.

Rubenstein, K. 2007. "Citizenship in an Age of Globalisation: The Cosmopolitan Citizen?" Law in Context 25 (1): 88-111.

Ryall, J. 2013. "Hopes Raised for British Parents Denied Access to Children in Japan," The Telegraph Online, 15 January. Accessed 24 October, 2015. http://www.telegraph.co.uk/news/worldnews/asia/japan/9803796/Hopesraised-for-British-parents-denied-access-to-children-in-Japan.html.

Ryrstedt, E. 2003. "Joint Decisions-A Presumptive or a Drawback in Joint Parental Responsibility?” Australian Journal of Family Law 17: 155-207.

Safety Network for Guardians and Children [ハーグ条約加盟に反対する会]. 2012. Safety Network for Guardians and Children, website. Accessed 14 February, 2016. http://hague-dv.org/.

Sagatun, I. J. and L. Barrett. 1990. "Parental Child Abduction: The Law, Family Dynamics, and Legal System Responses." Journal of Criminal Justice 18 (5): 433-442. http://dx.doi.org/10.1016/0047-2352(90)90058-J

Saltzman, S. R. 2009. "Christopher Savoie Follows Abducted Children to Japan, Gets Arrested," CBS News, 29 September. Accessed 30 December, 2014. http://www.cbsnews.com/news/christopher-savoie-follows-abductedchildren-to-japan-gets-arrested-photos/. 
Sekine, S. 2013. "Abe Intent on Child-custody Treaty, but Opposition Remains," The Asahi Shimbun AJW, 31 January. Accessed 25 February, 2013. http://ajw. asahi.com/article/behind_news/politics/AJ201301310089.

Shetty. S. and J. L. Edleson. 2005. "Adult Domestic Violence in cases of International Parental Child Abduction.” Violence against Women 11 (1): 115-38. http:// dx.doi.org/10.1177/1077801204271477

Slavin, E. 2015. “Congressman: Japan 'Breathtakingly Unresponsive' on US Child Abduction," Stars and Stripes, 27 March. Accessed 20 October, 2015. http:// www.stripes.com/news/congressman-japan-breathtakingly-unresponsiveon-us-child-abduction-1.336910.

Solove, D. 2007. The Future of Reputation: Gossip, Rumour, and Privacy on the Internet. New Haven: Yale University Press.

Squire, C., M. M. D. Davis, C. Esin, M. Andrews, B. Harrison, L. Hydén, M. Hydén. 2014. What is Narrative Research? London: Bloomsbury Academic.

Supreme Court of Japan [最高裁判所]. 2000. Shihō tōkei nenpō (kaji jiken hen) [司 法統計年報 (家事事件編) ]. Accessed 20 May, 2016. http://www.courts.go.jp/ app/sihotokei_jp/list?filter[type]=1\&filter[yYear]=2000\&filter[yCategory]= \&filter[mYear $]=\&$ filter$[\mathrm{mMonth}]=\&$ filter$[\mathrm{mCategory}]=$.

. 2005. Ko no hikiwatashi chōtei [子の引き渡し調停]. Accessed 10 June, 2016. http://www.courts.go.jp/saiban/syurui_kazi/kazi_07_09/index.html.

2011. Katei saibansho iinkaigijigaiyō [家庭裁判所委員会議事概要]. Accessed 14 February, 2016. http://www.courts.go.jp/tokyo-f/vcms_lf/111201kasaiiinkai gijiroku.pdf.

. 2014. Shihō tōkei nenpō (kaji jiken hen) [司法統計年報 (家事事件編)]. Accessed 20 May, 2016. http://www.courts.go.jp/app/sihotokei_jp/list?filter [type] $=1 \&$ filter[yYear] $=2016 \&$ filter[yCategory] $=3 \&$ filter $[\mathrm{mYear}]=\&$ filter $[\mathrm{m}$ Month] $=\&$ filter[mCategory] $=$.

Supreme Court of Japan (First Petty Bench) [最高裁判所第一小法廷]. 2013. Kansetsu kyōsei ni taisuru shikkō kōkoku kikyaku kettei ni taisuru kyoka kōkoku jiken [間接強制に対する執行抗告棄却決定に対する許可抗告事件]. Minshū [民集] 67 (3): 864.

Tanase, T. 2011. "Divorce and the Best Interests of the Child: Disputes over Visitation and the Japanese Family Courts." Pacific Rim Law \& Policy Journal 20 (3): $563-88$.

Terr, L. C. 1983. "Child Snatching: A NewEpidemic of an Ancient Malady." The Journal of Pediatrics 103 (1): 151-56. http://dx.doi.org/10.1016/S0022-3476(83) 80804-X

Toland, P. 2011.“Left-behind Parents Waiting," The Japan Times, 27 July. Accessed 30 December, 2014. http://www.japantimes.co.jp/opinion/2011/07/27/ commentary/left-behind-parents-waiting/. 
Tsuneoka, F. [常岡 史子], ed. 2013. Hajimete no kazokuhō [はじめての家族法], 2nd edition. Tokyo: Seibundō [成文堂].

U.S. Department of State. 2013. "Japan and International Child Abduction." Travel. State.Gov. Accessed 1 March, 2013; site now unavailable. http://travel.state. gov/abduction/country/country_5899.html.

U.S. Embassy in Japan. 2010. "Rapid Increase in Child Abductions to Japan." American View, 22 January. Accessed 11 October, 2015. http://amview.japan. usembassy.gov/wordpress/rapid-increase-in-child-abductions-to-japan/.

Vaulerin, A. 2013. "Le Japon Devrait Ratifier la Convention sur les Enlèvements d'Enfants," Libération, 22 February. Accessed 2 March, 2013.http://www. liberation.fr/monde/2013/02/22/le-japon-devrait-ratifier-la-convention-surles-enlevements-d-enfants_883961.

Vivatvaraphol, T. 2009. "Back to Basics: Determining a Child's Habitual Residence in International Child Abduction Cases Under the Hague Convention." Fordham Law Review 77 (6): 3325-69.

Waller, M. W. 2008. California Family Law for Paralegals, 5th ed. New York: Aspen Publishers.

Warner, R. W. 2010. "International Child Custody and Abduction under the Hague Convention." New York State Bar Association International Law Practicum 23 (Spring ): 50-54.

Weiner, M. H. 2004. "Strengthening Article 20." University of San Francisco Law Review 38 (4): 701-46.

White, M. I. 2002. Perfectly Japanese: Making Families in an Era of Upheaval. Berkeley: University of California Press. http://dx.doi.org/10.1525/ california/9780520217546.001.0001

Willacy, M. 2012. "Sayonara Baby." Foreign Correspondent, television broadcast. Australian Broadcasting Corporation. Broadcast 22 May. http://www.abc. net.au/foreign/content/2012/s3508549.htm.

The World Bank. 2016. Internet Users (per 100 People). Accessed 10 February, 2016. http://data.worldbank.org/indicator/IT.NET.USER.P2.

Yamashita, M. 2010. Watashi ga yūkaihan ni naru made [私が誘拐犯になるまで]. Tokyo: Taitoru [タイトル]. 